Acadiensis

Journal of the History of the Atlantic Region

ACADIENSIS

Revue d'histoire de la région Atlantique

\title{
New Voices in Regional Scholarship
}

\section{Suzanne Morton, Andrew Nurse et Donald Wright}

Volume 48, numéro 2, automne 2019

URI : https://id.erudit.org/iderudit/1067771ar

Aller au sommaire du numéro

Éditeur(s)

Department of History at the University of New Brunswick

ISSN

0044-5851 (imprimé)

1712-7432 (numérique)

Découvrir la revue

Citer ce document

Morton, S., Nurse, A. \& Wright, D. (2019). New Voices in Regional Scholarship. Acadiensis, 48(2), 177-178. d'utilisation que vous pouvez consulter en ligne.

https://apropos.erudit.org/fr/usagers/politique-dutilisation/ 


\section{New Voices in Regional Scholarship}

THIS EXCITING FORUM OFFERS US THE OPPORTUNITY to hear from some new voices and benefit from their perspectives on the history of the Atlantic region that has emerged over the last decade. It is also an occasion to gain some insights of where historical work on the region is going among a new generation of scholars. In this case, "New Voices" means doctoral students, recent graduates, and historians who are working outside academe and who are not often found in the pages of the journal.

This selection of five particular topics is by no means comprehensive and there are many "New Voices" and perspectives missing. One of the important issues we have unintentionally raised in conceiving of and publishing this forum is the relative invisibility of Newfoundland and Labrador and how its experience fits within regional historiography. Nearly 20 years after James K. Hiller asked "Is anyone interested anymore?" in creating a regional history, we have to conclude based on this forum's contribution that this question is still up in the air. ${ }^{1}$ Crossing the Gulf of St. Lawrence remains a challenge for Maritime historians and a parallel national Newfoundland history continues to thrive. The editors hope this lacuna will encourage work to specifically address this issue in forthcoming issues.

The five short essays here offer new insights but they also provide continuity with past scholarship. We encounter what might be considered "traditional" themes and interests, such as underdevelopment and life on the periphery, but these are recast with suggestive pathways to move forward. Phillipe Volpé's contribution on Acadian history highlights how past historiographical preoccupations with formal politics have inadvertently created a history without actual people. He offers suggestions for inserting people through entwining social and political history into place-based histories that link the local to larger movements with continuing and important resonance. Fred Burrill explicitly argues that "the fate of the Maritimes has always been tied up

1 James K. Hiller, "Is Atlantic Canada History Possible?" Acadiensis 30, no. 1 (Autumn 2000): 22.

Suzanne Morton, Andrew Nurse, and Donald Wright, "New Voices in Regional Scholarship," Acadiensis 48, no. 2 (Autumn/automne 2019): 177-178. 
in a world-scale struggle over resources, and that this struggle has manifested itself in the political structures governing the region" as he offers ways to think about this issue in the context of settler colonialism and the new history of capitalism. In “The Future is Mi'kmaq," Mercedes Peters notes the importance of recent work that emphasizes the experience of individual Indigenous nations with their specific experiences with colonialism. She also subtlety calls out most regional historians for reinforcing the relegation of Indigenous history to the pre-Confederation era. Lachlan McKinnon, in his wide-ranging piece, charts out the state of recent regional historiography and in particular highlights the importance of environmental history. Finally, Thomas Peace and Gillian Allen offer a model of collaborative opportunities and decolonizing the academy through working with Indigenous knowledge holders through the tentatively titled "Mi'kmaw Sovereignty Database." All those working in relevant archives are invited to participate in this project.

The intention of this selection of five essays is to be provocative, to highlight a diversity of opinion, and to promote scholarly exchange. In affirming the ongoing importance of a regional or place-based perspective, reframed by a transnational or global context or commitment to decolonization, they offer novel conceptualizations of place and new understandings of periodization. Close attention to the particular and the specific is not parochial or marginal; it is essential. We hope readers will be as convinced as we are of the health of the field and the real reasons for optimism about its future. As Fred Burrill concludes "Regional history is not dead, and [is] perhaps even more important than ever."

Finally, we would like to thank our authors and, of course, our assessors. In particular, we wish to flag that 48 years into the history of Acadiensis, we are pleased to publish our first contribution by a self-identified Indigenous person from the region. This is a milestone, and, as our new territorial acknowledgement indicates, this is something that we hope will soon become commonplace. 